\title{
Minority Language Maintenance: The Case of the Efik Language in South Eastern Nigeria
}

\author{
Offiong Ani Offiong \\ Department of Linguistics and Communication studies, University of Calabar, Calabar, Nigeria \\ Email: Offiongani2002@yahoo,com \\ Mercy I. Ugot \\ Centre for General Studies, Cross River State University of Technology, Calabar, Nigeria \\ Email: mercyugot@yahoo.com
}

\begin{abstract}
Language maintenance is a common feature amongst minority group and it is a phenomenon which will retard whole language shift for a minority language group. Language maintenance will only be possible if there is a high degree of contacts with a very influential language like English and conscious efforts by the language group itself. This paper examines the maintenance of the Efik language being a minority language in Nigeria, looking at the fact that the language is endangered. It takes into account some of the factors that lead to language endangerment worldwide and how to improve, standardize, revive, modernize its lexicon and ginger the Efik speakers. The Efik community of speakers have become bilingual over the years in the English language and are gradually shifting allegiance to English therefore losing their original heritage. We have used the 'reversing language shift theory' by Fishman (1991) as a framework to propose a checkmate to the extinction and the gradual shift the Efik language is experiencing. This paper highlights some preventive measures for the Efik language to be able to overcome the danger of losing domains in today's flow of globalization.
\end{abstract}

Index Terms —Efik, language maintenance, endangerment, globalization, extinction and shift

\section{INTRODUCTION}

The Efik language is one of the very numerous languages spoken in Nigeria. Grimes (2000) estimates that there are about five hundred (500) Nigerian languages. Of these, Hausa, Igbo and Yoruba are the very major languages spoken because they span through a vast expanse of land which covers about seventy percent (70\%) of the entire county. Also the population of the speakers are approximately ninety seven million $(97,000,000)$ of the one hundred and fifty million $(150,000,000)$ Nigerians. This shows that Efik is a minority language as we look at the sociology of Nigerian languages. The country has thirty six states in its federation units and Cross River is one of them. Over the years, Cross River State Community in Nigeria has been transformed from being predominantly bilingual to becoming a dynamic multilingual society. Udoh and Okon (2008, pp. 54-56) confirms that the number of languages spoken in Cross River State are about thirty five (35) from a census carried out by them. Of all of these languages, Efik is the most developed not because of its population but because of its early contact with the early European missionaries who brought in education and religion to placate the people of the area because of the slave trade business that was seen as unethical in the $16^{\text {th }}$, and $17^{\text {th }}$ and $18^{\text {th }}$ centuries. The coastal position of the Efik people allowed for the easy access and contact with these traders and later missionaries and educationists.

The Efik people who speak Efik language are situated in the South -South of Nigeria. Efik is a minority group language spoken in Southern Cross River, Nigeria. It is predominantly the speech form of Calabar Municipality, Calabar South, Odukpani, Akpabuyo and Bakassi local Government Areas. It is a second language to the surrounding neighbouring people and culture. Faraclass (1989) approximates that Efik has 360,000 speakers as first language and 2 million speakers as second language. The language has been variously classified as a member of the Lower-Cross group, of the Delta-Cross sub-family, which is an off shoot of the enlarged Cross River sub-branch that is a major constitution of the Benue-Congo family of the Niger Congo phylum (Faraclass 1989, Essien 2001, William and Blench 2000, Mensah 2010).

Numerous problems such as language endangerment, the loss experienced and factors contributing to language shift noticeable in Efik elicited the study of this paper. These problems are not peculiar to the Efik language, but to nearly all minority languages of the world. In trying to solve these problems, we believe we will come out with solutions of maintenance of the language.

As mentioned, one of the major concerns of this paper bothers on maintenance of the Efik language which is a minority language in Nigeria. In the midst of Efik, English, Ibibio, Ejagam, Lokaa and Bekwarra, are largely spoken within and around the domain of the Cross River State Southern Senatorial District. If the Efik people do not maintain their language, then there is the tendency of experiencing language shift. Hoffman (1998) has observed that under 
certain cultural, social and political conditions, a community might opt to change one set of linguistic tools for another. Efik language is not opting to shift to another language, but is faced with the predicament of other languages dominating it. The Efik community is not immune to the language loss phenomenon, but this study stands out as one of the first to charge the community of being aware and conscious of language shift and eventual extinction.

One of the objectives of this paper is to invigorate the attitude of the Efik speakers, their internal thought, feelings and tendencies in behaviour. This triggers them to ensure they are conscious of maintaining their language. This study will investigate whether there is language shift among the Efik natives and try to identify the roles played by them in the shift and maintenance of their language. The following research questions will act as a compass to ensure that we do not veer out of scope:

(a) Are minority languages including Efik prone to experience loss, shift and endangerment?

(b) Are enough efforts being made to ensure that the Efik language is being revitalised and maintained?

(c) Using the literature and the theories of various scholars, will they provide enough buffer for the revival of the language?

(d) Will the Nigerian language policy question been answered?

(e) Efik language was the second language in Nigeria to have an orthography, to have a writing system and was the first to have a dictionary, why shouldn't vigorous efforts be put to stop it from drifting into gradual extinction?

\section{SIGNIFICANCE OF THE STUDY}

Language contact is usually the reasons for language shift. Where contact exists and there is competition, the tendency is for the stronger language to draw more speakers towards it thereby engineering language shift. It is only a conscious effort of maintenance that can stop this shift. In the community where Efik is spoken, English is spoken by everyone. Ibibio also has a strong presence thereby making Efik less 'attractive'. Also, parents in many families are not doing the language any good as they speak mostly English with their children. In cases like these, some language scholars of Efik decent have resisted this shift by writing literature and grammar books which have managed to maintain the language attitudes. Linguists like Essien (2001), Offiong (2005, 2006 and 2012), Mensah (2010), have tried consciously to maintain Efik by ensuring that linguistic materials are made available, teachers of the language are also strongly encouraged to be interested in teaching from primary through the secondary up to the tertiary level. Efik even has a better advantage when compared to languages in the same geographical domain. Some scholars like Ward (1933) and Goldie (1862) had interest in Efik language and developed its orthography as far back as the late 1800s. This made Efik develop a dominant status deriving from the practical need to communicate along the Cross River Basin. Udoh and Okon (2008) confirms that:

A typical example is the Efik language which had been used along the Cross River Basin as a huge lingua-franca for trade, education etc. The language had an orthography, a dictionary and a full Bible translation in the $19^{\text {th }}$ century. This was uncommon in most Nigerian languages. However, it is gradually being replaced by other local languages. These languages are even being used in churches where Efik had been in use, as some kind of liturgical language (p. 68).

This study is interested in looking at how linguistic scholars of Efik decent are working on the maintenance of the Efik language. There is a strong signal that the language is on the path of extinction. Languages like kiong, Efut in the same geographical domain are dead already. There is therefore, a strong consciousness in the area of maintenance of the language.

\section{A. Literature of Previous Studies}

Minority languages are prone to endangerment, therefore the need to maintain these languages arise. Brenzinger (1992) looked at the extent and types of endangered languages and language maintenance trying to document and view the following languages' survival abilities. The languages are Ainu in Japan, Nivkh in Russian Federation, Amazigh (Berber) languages in North Africa and North Frisian in Germany. He noted that languages are in danger when its speakers do not pass these languages to the next generation. He noticed that today, all the languages he documented and studied are shrinking and will ultimately vanish, if these developments are not reversed. This is the experience noticeable with the Efik language. This is seen as we observe and carry interviews with our respondents. He also mentioned that the size of a community affects the threats the language faces because they are surrounded by larger languages. The Efik language is surrounded by larger communities, thus making it face the same threats.

Having examined his view on endangerment, he focused on maintenance and revitalisation. Maintaining language diversity requires not only the speakers themselves, but also the involvement of linguists, language planners and policy makers. He believes research on endangered language communities must be reciprocal and collaborative. This approach is what this study will eventually propose for use as it concerns the Efik language.

At this point, it is necessary to discuss a little bit about language planning in Nigeria as an insight into what happens to the Efik language. Language development projects are not taken seriously in Nigeria. The government will set up agencies, centers and commissions like the Language Development Center of Nigeria Education and Research Development Council (NERDC) in Abuja and National Institute of Nigerian Language (NINLAN) in Aba. These centers would formulate policies but government would either not implement or would be slow in implementation of these language policies. Until Nigerians see the needs and benefits for studying their languages, the use and study of 
these languages will remain largely, if not wholly academic. Linguists of the three major Nigerian languages decent are working hard to ensure their languages continuously grow. Other linguists from the minority areas are just recently realizing that their languages are gradually shifting and experiencing loss, hence, they are putting in efforts to make their languages visible. In NERDC and NINLAN, efforts are being made to ensure that these languages are developed to have lexicons that can be used teach any subject or course in schools. Also, many universities in Nigeria have Nigerian languages departments that various indigenous languages are taught. Language planners are really working to ensure that most minority languages develop a writing system. Some of this languages do not have orthographies. However, the cases are gradually improving. Maintenance consciousness is slowly creeping in, (Offiong and Mensah:2012). The Nigerian language planning question is being answered here.

A study of the maintenance of the Malaysia's languages show cases how minority languages are maintained. Mohideen (2008) says that the minority languages certainly face an uphill task to remain as a truly living language. He says if we consciously choose to ignore the survival of these minority languages, we become responsible for their language genocide. His suggestions that minority language communities should develop strong internet medium as a way of sustaining their language. Crystal (2002) advocates the use of technology to make the languages continually visible. Using these suggested medium, Efik is likely to benefit from these mode of maintenance.

The theoretical assumption that underpins this work is the central component of Fishman's (1991) intergenerational transmission which surround reversing language shift (RLS) theory. It demonstrates the dynamic fluid and varied nature of intergenerational transmissions in the Efik language community under study. We are also finding out how crucial Fishman's model is to the theory and practice of minority language survival (King \& Logan-Terry: 2008). Reyhner (1999) points out that Fishman believes that the intergenerational transmission of language in the home from parent to young children is the key to keeping indigenous languages alive; however, schools can play either a positive or negative role in supporting the efforts of indigenous parents and communities.

\section{B. Factors Contributing to Language Shift and Death}

One of the major factors causing the gradual shift of Efik language to the English language is the economic strength and function that is attached to the English language. Holmes (2008) points out that in countries using English as its official language, "people learn English in order to get jobs". She also says that "communities see no reason to take active steps to maintain their ethnic language. They may not see it as offering any advantages to their children, for example". Again according to her, "they may not realize that it is in any danger of disappearing" (p. 60). Without active language maintenance, shift is almost inevitable in many contexts.

In the Nigerian context, major institutional domains - schools, television, radio, newspaper organisations, government administration, courts, civil service amongst others - use English as the medium of communication. This situation is gradually leading to language shift, that is, from Efik to English. And except the natives (Efiks) take active steps to prevent it, the inevitable will happen.

Another factor that contributes to language shift and death is urbanization. This is basically demographic. Speed of language shift is more noticeable in urban areas than in rural areas. This is because rural groups tend to be isolated from the centre of political power for longer time, and they can meet most of their social needs in the ethnic or minority language, (Holmes, 2008, p. 61).

Again, population is another factor. Language shift is a common phenomenon when it comes to the developing countries of the world. Examples are bound in Asia and other African countries. Even within a country, minority language groups are suffering from this shift syndrome. In Nigeria for example, the three major languages of Yoruba, Hausa and Ibo are dominant languages that pull other minority languages. Standard English and the Nigerian Pidgin even make it worse in the sense that it is more spoken by a larger population and thereby making the minority language speakers like the Efiks tend to abandon their language and go for the more spoken languages.

Also, lack of education amongst speakers of a particular language encourages shift and eventual extinction of that language. Even very educated indigenes of a particular ethnic group look down on their own language thinking that other languages are more superior to their language. The Efik people are suffering from this challenge. They ignore their language and speak mostly English or sometimes Nigerian pidgin in their homes. Efik language is even better off when compared to other languages in the same geographical area. The Efik language had an orthography as early as the nineteenth century, had a dictionary, had bible translation and was used for commerce purposes in that century. This was not enjoyed by other language communities in the same vicinity like Ejagam, Ibibio, Bekwarra amongst others. Speakers of these other languages are educated no doubt, but are not interested in the education in their various languages.

\section{METHOdOLOGY AND SAMPLING}

This study used more of qualitative methodology to collect data, which are mostly verbal descriptions and explanations. Our class of research methods were both participant observation and in-depth interviews. We joined the daily lives of the various families over a period of three years. In the process, we selected highlighted problems associated with minority languages, looking at the concepts and indices. Our aim for observing was to check on the frequencies of proficiencies and attitudes of the respondents. We incorporated Fishman's theory to aid in the findings of 
this study. In the course of this study, we developed a very good rapport with all members of the families. We had interviews with the parents and children.

The samples chosen for this study are limited to the parents and children that reside near the University of Calabar campus and who spend all their time in the urban Local Government Areas of Calabar Municipality and Calabar South. These samples population were chosen here because the university environment provided the platform we required, that is, a strong urban environment.. The average time they have lived in this environment has been five years.

We choose twenty families, ten from Calabar Municipality and ten from Calabar South as our research population. In each of the household, there were an average of six (6) people, making a total of one hundred and twenty (120). Of these number, forty (40) were adults and eighty (80) were children. Our children respondents were aged 11 and above because they could use language with ease. For the parents, we mostly interacted with their mothers because they were with these children more often than their fathers. We selected our population through random sampling of a larger population around the university environment. The goal of this study informed our using this sample size. We needed to be very close to them. Also, precision is required in studies of this nature. We used two local government areas, even though both urban, to categories the sample of the two groups to compare their changing attitudes towards language shift from the Efik language. We carried out these study through observations and structured interviews from all the respondents. The observation and interviews covered;

A. Language Proficiency

B. Attitude towards English,

C. Attitude towards Efik,

D. Attitude towards bilingualism and

E. Language maintenance.

During the three year period, we spent one day a week observing each of the twenty families, making it an average of eight visits to each of these families. We spent a whole day with them, watching all their activities, especially their language behaviour. We were also discussing with them as we asked them questions relevant to our study. Our interviews were structured. As the observations were going on, we were taking notes of all we required using the research questions as our guide.

\section{FINDINGS AND DisCUSSIONS}

\section{A. Language Proficiency}

The respondents - both children and mothers were asked to report on the use of Efik and English languages. Our observation revealed that for the children in Calabar Municipality, there was a decline in proficiency in Efik, while their proficiency in English was on the increase. For the mothers, their proficiency in Efik was still high, they also had high proficiency in English. For the children in Calabar South, their proficiency in Efik was on the decline, while that of English was on the increase. For the mothers, most of them had very high proficiency in Efik and had lower proficiency in English. This did not stop them from speaking more of English to their children. It appeared that speaking English to the children was more in vogue than speaking Efik. Comparatively, the children in Calabar Municipality had a higher proficiency in English than the children of Calabar South Local Government Area. The reason could be adduced to the fact that Calabar Municipality was more urban when compared to Calabar South Local Government Area. The children of Calabar Municipality were losing their $\mathrm{L}_{1}$ faster than the children of Calabar South. There was a sure level of loss in the two local government areas. In the two local government areas, none of the children could even write the Efik language, most of them understood the Efik but could not speak fluently. Obviously, the society is a multilingual society, but most of those studied were bilinguals. We noticed that it was social reasons that made the children prefer using a particular code. The Efik community in the next generation may lose their language because there is a gradual shift to the English language even though this phenomenon is gradual. Holmes (2008) puts it this way.

When a language dies gradually, as opposed to all its speakers being wiped out by a massacre or epidemic, the process is similar to that of language shift. The functions of the language are taken over in one domain after another by another language. As the domains in which speakers use the language shrink, the speakers of the dying language become gradually less proficient in it, (p.58).

This is what is gradually happening to the Efik language. Research question (a) is answered by the above discussion. The attitude of the Efik families show that the language is prone to loss, shift and endangerment, therefore the need for maintenance.

\section{B. Attitude towards English}

Our respondents in the two Local Government Areas had very positive attitudes toward the English language. They looked and seemed happy using the English language which was their $\mathrm{L}_{2}$. Question posed to them revealed a 100 percent positive attitude towards the use of the language. This positive attitude indicated that they were proud of using the $\mathrm{L}_{2}$ even more than their $\mathrm{L}_{1}$. Their mothers and the children themselves used English while communicating with each other. 70 percent of the children confirmed that they were encouraged to use English more in communication by their mothers. The reason was that in schools, it was English that was the language of instruction in every subject. It was therefore necessary, that they be proficient in English. Their mothers encouraged them so that their lexicon should 
improve, and also that they could use standardize English at the detriment of the $\mathrm{L}_{1}$ - Efik. Holistically, this is not good enough for the development of Efik language which is their mother tongue. Most minority languages in Nigeria suffer from this same fate. This attitude is one of the major obstacles to the development of the heritage language. It is also established that intelligibility affects attitudes. People find it easier to understand languages and dialects spoken by people they like and admire. As the children have contacts in schools and their new academic environment, they admire subconsciously, their teachers and other children that speak English better than them. They get motivated and acquire the English language faster because they feel positive about their $\mathrm{L}_{2}$. These children generally held positive attitude towards the English language in these two local government areas under study because of the people who they see speak the language. We noticed that the children admired the contexts and functions with which English is associated.

"Generally, attitude to language are strongly influenced by social and political factors", (Holmes, 2008, p. 406). She further posits that, "language planners must take account of attitudes when they select a suitable language as an official or natural language. Language attitudes are very sensitive to social and political changes". They can have a great influence in areas such as education. It is for this education sake that Efik language is suffering. The shift the language is experiencing is greatly because of this. This attitude to the English language is gradually killing the Efik language. For the sake that English is the official language of Nigeria and there are about five hundred other indigenous languages in the Country, English will continuously attract positive attitudes from the younger generation which are currently being studied. These Efik children see the English language as having overt and covert prestige.

The social acceptance and conformity notion by Filmore (2000) buttress the strong likeness for the English language when compared to the Efik language. English in this context of study is the dominant language because it is the language the younger generation is looking forward to speak. This gives us cause for concern, because it is not a good sign for the Efik Language.

\section{Attitude towards Efik}

In the case of attitude towards Efik, we got varied responses from our respondents. From the questions relating to the use of their attitude towards Efik language in the two local government areas, we realized that all the mothers except two in Calabar Municipality spoke Efik fluently and were in diadem with the usage of the language. However, speaking Efik to their children was minimal because they were conscious of them learning to speak and write English well in their schools. It is important to state that all the children questioned understood Efik well. 55 percent of them could speak the language fluently but none of them could write their $\mathrm{L}_{1}$.

On close enquiry, they all complained that there was no incentive or advantage for them to speak or write Efik. Nothing in school was done in the language, it was not even a West African Examination Council (WAEC) subject. In most of the homes 75 percent of their mothers spoke Efik at home to their children, but 65 percent of the children responded in English. They were not interested in their linguistic identity. The result of these findings was shocking enough to trigger our desire to look at the maintenance of the Efik language. Burnaby (1980, p. 21) indicates that "when many speakers of two or more languages are in regular and significant contact, it is likely at times that the speakers and the language will change in some way... one might give way entirely or partially to the other...". As it stands in the Efik domain, it looks as if Efik is gradually giving way to English even though the process of shift is slow. We are trying to stop the shift in totality.

As literacy increases, western education becomes better, native languages become moribund. Efik parents are committing 'linguicide' by not encouraging their children to speak and write the Efik language. We also observed that in all the homes we worked with, code-mixing and code-switching was very high amongst the children. The children that managed to speak Efik at all, code-mixed very strongly.

As we carried out this study, we noticed that children's attitude towards Efik was not positive, The evidences are clear because the children did not see reasons why they should speak Efik, since in schools, it is not part of their requirements. The see the Efik language as not having enough legacy of overt prestige. It does not show any symbol of nationhood. This attitude of the children which is not good enough for the development of the language stands as a hindrance for Efik language maintenance. In the history of languages in Nigeria, the Efik language was one of the first languages studied by the European missionaries. By 1862, the first indigenous language dictionary was published in Nigeria by Rev. Hugh Goldie. It was an Efik dictionary. In the same year, Efik language was used in the first bible translation in Nigeria. The first Efik indigenous grammar work was written and published in 1933 by I. C. Ward, a British linguist.

In spite of all these firsts, other indigenous Nigerian languages have come to be more visible and have taken over premiership in scholarly works. Yoruba, Ibo and Hausa have developed more linguistic relevance than Efik. The language policy in Education in Nigeria encourages the study of a local language in the area it is spoken in schools, but in the five local government areas where Efik is spoken, it is hardly taught. Instead, Ibo and Yoruba are taught in these schools. These hindrances have strongly stood out as challenges to the Efik language. The children do not see any reason why they should study Efik, hence the development of the negative attitude.

Attitude towards Efik is strongly unfolded by the difference and divergence notion by Fillmore. The children act in a divergent manner when it comes to speaking Efik. This section and the previous one further confirms research question (a). 


\section{Attitude towards Bilingualism}

All the respondents for his study are bilinguals with various degrees of performance level in English and Efik. All the mothers interviewed (90\%) apart from four (i.e. 10\%) feel that it is important to speak in English and Efik. For the children, sixty five percent liked the use of Efik for communication. Thirty five percent of them felt that it was not necessary using or understanding Efik. Eighty percent of the children felt it was difficult being bilinguals, while 100 percent of the mothers felt it was not difficult in any way. Kuncha and Bathula (2004) opined that "there appears to be a close relationship between the perceived difficulties and the need to be a bilingual speaker. In general, attitudes reported towards bilingualism are consistent... where mother's reports are more favourably inclined than the children".

Bilingualism is strongly the overall concept of this study. As we carried out our observations and interviews, we realized that the mothers and the children where enveloped in the spectacles of language choice. As an area under language choice, we noticed the following - code switching, code-mixing and code-shifting. The children, we observed, code- switched more than their mothers. They were successfully using the alternate codes especially when at home. This is what Banjo (1983) referred to as "a phenomenon in which in a special event, two interlocutors make sentences sometimes in "English" and sometimes in 'Efik'. In as much as their mothers code-switched when in discourse with their children, they more- often- than not code-mixed than code-switched. Their random alternation of English and Efik were more within the sentence of the two languages. Banjo (1983) calls this action of theirs, language mixing.

Also, another bilingualism concept we noticed amongst the children more than their mothers was code-shifting. Lawton (1979) indicates that this is the result of speakers movement from one language to another". He says "this movement is conditioned by social as well as linguistic constraints. The linguistic constraints are those of proficiency and mastery of one language over another. Code-shifting takes place at the phonological, morphological, syntactic and semantic levels.

Put together, all mothers commented that their children mixed English words with Efik. The respondents were not enthusiastic or proud of their bilingual ability. Only parents were favourably inclined towards bilingualism. This indicates that there is perceptible shift from Efik to English. As bilingual children and mothers under study it was noticed that there was a linguistics deficits. We noticed that the children - especially the older ones linguistically experienced deprivation based on the test we carried out. The children as bilinguals preferred English and used it more because of its social acceptance. The language was more in conformity because it was the dominant language in their schools. The deficiency was in Efik which is their mother tongue. The verbal skills by the children was openly seen. They first come into school as monolingual children (not all). They become bilingual as they are in contact with the L2 (English). As they progress into higher classes, they become bilingual, we noted that their mothers are already bilingual.

At this stage, bilingualism is an asset to the children. It clearly functions to them as the equivalent of a linguistic prestige. At higher classes, English becomes dominant as they drop vernacular forms. At this point we noticed the pattern of linguistic change. This language changed progressively from vernacular to English for these children. The difference and divergence notions of Fillmore clearly gives us a clear picture what happens to these bilingual children and their mothers. This Fillmore's notion clearly answers question (c).

\section{E. Language Maintenance}

From our investigation, it is obvious that the Efik language is gradually shifting to the English language and maybe partially to the Nigerian Pidgin in terms of usage. This is noticeable in the constraints on language choice faced by the Efik children. We can ascertain that the future does not augur well for the language since there is an eminent death. But this will be the truth if nothing concrete is done as a form of maintenance. Already two languages in the same domain kiong (spoken by the Okoyong people of Odukpani Local Government Area) and Efut (spoken by the Efut people of Calabar South Local Government Area) are already moribund. The Efik language has been favoured over time because Christian missionaries and early educationists had developed an orthography as early as the $18^{\text {th }}$ century. Bible and church hymns had been translated at that period. Even though it was a minority language within the area, (there were the Ibibio, Ejagam and Bekwarra languages that were majority in number in terms of population,) Efik was still far developed.

'Bottom to top' death is what the language is gradually experiencing, that is, at the home level, the language is not spoken by most of the children at home, particularly in the urban areas. As literacy increases, western education becomes better, native languages-(Efik) becomes moribund. We have therefore come to the consciousness that language maintenance is crucial for the survival of the Efik language. From the interview carried out for this study, we realized that six mothers loved their language - Efik. They loved Efik folklores, songs and the culture of the land. Speaking English with their children was just an unconscious attitude which was done for the sake of the children doing well in their schools. The children themselves were not very interested in the Efik language. Only a reasonable twenty five percent were interested. Maintenance therefore, becomes very necessary for this language.

To maintain Efik language is quite crucial. We are using the reversing language shift theory by Fishman (1991) to propose a checkmate to the shift from Efik to English. This will act as a revival. Crystal (2002) proposes six factors which may help language maintenance. His proposals are based on Fishman's (1991) framework of evaluating language endangerment which serves as one of the strongest attempt used in maintaining minority language. It provides the 
underpinning which this study used in carrying out its survey. He postulates that an endangered language will progress if its speakers:

1. Increase their prestige within the dominant community

2. Increase their wealth

3. Increase their legitimate power in the eyes of the dominant community.

4. Can write down the language

5. Have a strong presence in the education system

6. Can make use of electronic technology.

The result obtained from this study has gingered some linguistic scholars identify several prestigious citizens of Efik decent and they are working together to encourage the use of Efik at home and at certain functions that require the use of native languages like in marriages, burials, meetings etc.

All Efik sons and daughters holding political offices and top executives have been sensitize. They are to encourage their wives at home, their children, their relations to use Efik language more often in their everyday activities except when it is official.

Every teacher/writer of the Efik language is being encouraged with incentives from prominent Efik sons and daughters. The Efik traditional king - Obong of Calabar is presently awarding scholarships to students willing to study Efik at all levels of education. Research question (b) is being tackled here, and conscious efforts are being made to revitalise and maintain the language.

To show how Efik is gradually becoming extinct, the language was a subject taken at the Senior Secondary Schools level conducted by the West African Examination Council (WAEC) up till 1979. In 1980, WAEC dropped the language because students were not registering for the subject any longer. But there is good news. A group of young Efik linguists are working seriously with the two examination bodies WAEC and the National Examination Council (NECO) to bring back the language as an examination subject. The teachers who are already in their retirement age are to take contract jobs with the Cross River State Government and with private schools as a way of sustaining the teaching of Efik in secondary schools. They are also encouraging younger teachers to take up Efik as a subject so that they can replace the old ones retiring.

Efik language had the fortune of being written as far as 1800. By 1862, Rev. Huge Goldie had developed an Efik dictionary. Up until 1979, pupils and students in primary and secondary schools were taught how to read and write Efik. Even at the Cross River State College of Education in Akamkpa Efik was taught as a subject. But today, the children in schools cannot read not to even think of writing in the language. Using Crystal's theory of learning language shift and the intergenerational transmission of Fishman (1991), the few linguists in the society are propagating and putting heads together to ensure the teaching of Efik in primary and secondary schools in the locality is made compulsory. They are doing everything possible to make the Cross River State Government to see reasons why Efik should be taught at this level and the reading and writing skills are strongly pushed forward as a means of encouragement. Also the scholars are working in partnership with the State Ministry of Education, and the State Governor to encourage the beefing up of the Efik language curriculum so as to input it in the study scheme in the education system. They are sensitising parents to strongly transmit the Efik language to their children.

In the University of Calabar, there is Professorial Chair sponsored and instituted by a former Senator of the Federal Republic of Nigeria - Senator Bassey Ewa Henshaw - On Indigenous Languages, Culture and History of the Cross River State people situated in the Department of Linguistics and Communication Studies. This sponsorship is encouraging the teaching and learning of indigenous languages especially. teachers of Efik are being encouraged to write books in Efik literature, grammar and other areas that will be of benefit to the Efik language towards ensuring language growth and development.

We realize that the native speakers of Efik are not even conscious that they are losing their identity and their language gradually. With constant sensitization the Efik community is becoming aware that its language is in danger of disappearing and they are taking deliberate steps to revitalize it. Attempts are seriously made to the language shift, therefore we are revitalizing it. The Efik people are lucky because the language loss has not reached a point of no return. We know it is an attitudinal factor that has led to the level the language has found itself. But scholars are working on the attitude of the people to revive the language and bring it back to where it was before 1970. The effort they are putting to maintain this language is conscious and concerted.

The conscious and concerted efforts are seen in the area of encouraging broadcasting in Efik language. Efik news, Efik plays, personal paid announcements and advertising copies are now being carried out in Efik language. Even though these scholars cannot as at now establish a deviated Efik language television channel, they are establishing successful bilingual education programmes which extend from pre-school to tertiary level. In addition to broadcasting, the Federal Government of Nigeria has established a meta- language committee on indigenous languages Efik inclusive. A lot of work is done here to develop Efik language. These scholars are also encouraging worship centres to use Efik language as a means to increase the chances of language maintenance. Again research question (b) has been taken care of here. Holmes (2008) postulates that;

Institutional support generally makes the difference between success and failure in maintaining a minority group language. Education, law and administration, religion and the media are crucial domains from this point of view. The 
minority group which can mobilize these institutions to support language maintenance has some chance of succeeding. When the government of a country is committed to maintaining or reviving a language, it is possible to legislate for its use in all these domains... (p.65).

Researchers are sensitizing Cross River State Government to encourage the use of indigenous languages from the perspective of socio cultural, economic, political, institutional, demographic, attitudinal, and educational dimensions so that the indigenous languages will be maintained, especially Efik. Vigorous efforts are being put in by the Cross River State Government, The Federal Government of Nigeria, The Department of Linguistics and Communication Studies, University of Calabar and a Centre for Indigenous Language in Calabar to invigorate the Efik language. Workshops, seminars and lectures are consciously organise for this development. This little, but concise efforts will surely yield results to the advantage of the Efik language. Revised orthography and development of new lexicons are being put in place by Efik linguists so as to develop the Efik language and move from the loss level to the revitalised level.

\section{CONCLUSION}

The results and interpretations of this survey as seen in this study shows that $100 \%$ of all the respondents, both parents and children had a positive attitude towards the English language as against the Efik language. 55\% of the Children we worked with understand and speak Efik, even though not strongly. 90\% of the parents feel Efik and English should be taught and spoken to the children at home and in schools as a way of strengthening the Intergenerational Transmission Theory of Fishman. 60\% of parents want Efik language featured in the internet connections - Facebook, Twitters, YouTube social communication networks etc. This survey shows why Efik has to strongly and vigorously promoted. Efik was the second language in Nigeria after Yoruba to have a writing System. It was the first to have a dictionary and the first also taught in school in Nigeria. It will be a shame to have it extinct.

The rate at which minority languages in Nigeria are shifting or gradually experiencing loss calls for this study. Language maintenance is crucial for the survival of these minority languages. This study clearly reveals evidence of loss of Efik and other Indigenous Languages, because of its contact with the more developed English used for business, education, governance and worship. Maintenance of these languages are too relevant at this point to avoid "total extinction", like Efut and kiong which are in the same domain as Efik that are already moribund.

This work is fashioned out from the ambience of sociolinguistics. Ideas were picked from various framework. From the analysis drawn, we have concluded that where a local language is placed alongside English, the bilinguals certainly prefer to settle for English. As the natives write and read more of English, their native language reduces. Despite the children's strength in listening and speaking skills, they were not fluent in their mother tongue. Writing and reading skills are greatly reducing. They were not interested in writing or reading Efik.

The study shows that both mothers and children have less positive attitude towards Efik than English. It is only through concerted efforts that maintenance is bringing Efik back to the front burner. that is, the language is gradually being revitalised. For most Efik children, the language is no longer a strong native language. Transmission in this language is greatly reduced and this is not good enough for the growth of the language.

This study has revealed that, the Efik community must be the central decision maker in any initiative on Efik language maintenance. They must see maintenance as a strong priority to resolve the issues of language loss, shift and extinction. There is however, a consolation that Efik language scholars and linguists are working towards a maintenance policy that will see the language grow, develop, improve, get standardized, ensure modernization of its lexicon and revive its literature and grammar. The preventive measures to avoid the decline of the language are to ensure that the natives are prestigious enough to encourage the current generation to emulate the wealthy ones. Also the society's 'big wig' that use the language should have a backing, if possible a legislation that will encourage the use of the native language in policy making, education, information (media) amongst others. Emananjo (1990) examines the fate of minority language in the educational system and report that the fate of these languages is primarily in the hands of their speakers. Speakers should therefore, take bold steps not only to use their language themselves, but to ensure that their children are adequately exposed to it and retain it as their home language to pass on to the next generation.

With all the consciousness of Efik language maintenance, the language community faces a dilemma regarding two seemingly conflicting goals whether to preserve linguistic identity or improve their children's English language skills that are essential for their active professional career. However, it is believed that both goals are achievable concurrently. This will be beneficial to the Efik community, the Cross River State community and even Nigeria as a whole. This study tries to encourage parents, teachers and language scholars to join forces with each other in promoting their own language. All these actions are taken for the goal of preserving the ethnic language and culture.

\section{RECOMMENDATIONS}

In order to enhance the strength of Efik and other 'minority' language, the following are recommended:

1. The promotion of bilingual education in the mother tongue and English.

2. Nigerian government at both the Federal and State levels should re-view the language provisions of the national policy on education in a more positive and unambiguous way. 
3. The Efik language should be included as a school subject and constant monitoring of the schools should be carried out.

4. Scholarships should be awarded to young school leavers who are interested in studying indigenous languages at the National Certificate Examination (NCE) and the degree level.

5. Intergenerational transmission should be a compulsory feature.

\section{REFERENCES}

[1] Banjo, A. (1983). Aspect of Yoruba- English language Mixing, Journal of Nigeria language. 1. (3).17-25

[2] Brenzinger, M. (ed.). (1992). Language death, factual and theoretical explorations with special reference to East Africa. New York: Mouton de Gruyter.

[3] Burnaby, B. (1980). Language and their roles in educating native children. Toronto: OISE Press

[4] Crystal, D. (2002). Language death and diversity. Google books. http//booksgoogle.com/books/about/language_death.htm/Retrieved 10 $0^{\text {th }}$ March, 2012.

[5] Emenanjo E. N. (1990). Multilingualism, minority languages and language policy in Nigeria. Agbor; central Book Ltd.

[6] Essien, O. A. (2000). Code switching and code mixing in Nigeria. Klabara: Journal of the Humanities. 6. (2). 1-8

[7] Essien, O. A. (2001). Ibibio in Gary Jane and Carl Rubino (ed), Facts about the world's languages: An Encyclopedia of the world's major languages, past and present. Ny and Rubhin; A. W. Wilson, 317-321.

[8] Faraclas, N. (1989). The Cross River language, the Niger -Congo languages, ed. by John Bendor -Samuel, 277-294. Lanhaum: University Press of American.

[9] Filmore L. (2000). Lose of family language: should education be concerned.? (retrieved from the internet on 10 ${ }^{\text {th }}$ July, 2011) http://www. Jster. Org/.

[10] Fishman, J A. (1991). Reversing language shift (retrieved from the internet on 10 $0^{\text {th }}$ July 2011.) http:// www.Youtube. Com/.

[11] Hoffman, C. (1998). An Introduction to Bilingualism. London: Longman Group.

[12] Holmes, J. (2008). An Introduction to Sociolinguistics. England: Pearson Education Ltd.

[13] Goldie, H. (1892). Dictionary of the Efik Language. Glasgow. United Scotland Mission.

[14] Grimes, B.(ed.) (2000). Ethnologue: language of the world. $14^{\text {th }}$ Edition. Dallas. SIL International.

[15] King, K. \& A. Logan-Terry, (2008). Additive bilingualism through family policy: Strategies, identities and interactional outcomes. Calidoscopio 6 (1), 5-19.

[16] Kuncha, R. M. and H. Bathula, (2004). The role of attitude in language shift and language maintenance in a new immigrant community: A case study. University of Waikato language institute, Auckland Centre, New Zealand working paper 1. April 2012. http//www.crie.org.nz/researchpaper/H.Bathula_WPI.Pdf

[17] Lawton, D. L. (1979). Paradox and paradigm: Language planning and language teaching in Jamaica. W. I. (214), 167-171.

[18] Mensah, E. (2010). The morphosyntax of code-mixing: the Efik-English perspective. Concentric: Studies in Linguistics. 36 (2), 235-256.

[19] Mohideen, H. (2008). Survival of the minority Kristang language in Malaysia. Language in India. 8 (2), 1-18.

[20] Offiong, O. A. 2005. Languages in contact: The case of Efik and English. In Calabar journal of liberal studies (CAJOLIS). 8. (1). 123-138

[21] Offiong, O. A. and S. Obute. (2006). Tense, Mood and Aspect: A Feature- Geometric Approach. Calabar Studies in Languages, (CASIL). 13 (1), 30-46.

[22] Offiong, O. A. \& E. O. Mensah.( 2012). Language choice and family language policy in inter-ethnic marriages in South Eastern Nigeria. Cscanada, Studies in literature and language. 4 (2), 96-104.

[23] Reyhner, J. (2003), "Some Basics of Indigenous Language Revitalization", In Jon Reyhner, Gina Cantoni, Robert St. Clair and Evangeline Parsons Yazzie (eds.) Introduction to Revitalizing Indigenous Languages. Flagstaff, AZ: Northern Arizona University. Online at http://jan.ucc.nau.edu/ jar/NNL. Retrieved June 9, 2012.

[24] Udoh, I. \& B. Okon (eds.). (2008). The languages of the Niger Delta region of Nigeria. Lagos: Concepts Publications Ltd.

[25] Ward, I. C.(1933). The phonetic and tonal structure of Efik. Cambridge: Heffer.

[26] Williamson, k \& R. Blench. (2000), Niger-Congo in Heine \& Nurse (ed). African Languages: An Introduction. Cambridge: Cambridge University Press. 11-42.

Offiong Ani Offiong is an Associate Professor in the Department of Linguistics and Communication Studies, University of Calabar, Calabar , Nigeria. He has been the Head of Department (2008-2010) and is presently the Sub-Dean of Faculty of Arts, 2010 - date. He holds a B.A. (Hons.) in Linguistics, a Masters and a Ph,D in Sociolinguistics in 1983, 1986, and 2007 respectively.

Mercy I. Ugot is a Senior Lecturer in the General Studies Department, Cross River State University of Technology, Calabar, Nigeria. She is currently overseeing the Department (2012). She holds a B.A. (Hons.) in French Language, M.A and Ph.D. 